\title{
Beta 1 integrin predicts survival in breast cancer: a clinicopathological and immunohistochemical study
}

Petra Barros dos Santos ${ }^{1 *}$, Juliana S Zanetti ${ }^{2}$, Alfredo Ribeiro-Silva ${ }^{2}$ and Eduardo IC Beltrão ${ }^{1,3}$

\begin{abstract}
Background: The main focus of several studies concerned with cancer progression and metastasis is to analyze the mechanisms that allow cancer cells to interact and quickly adapt with their environment. Integrins, a family of transmembrane glycoproteins, play a major role in invasive and metastatic processes. Integrins are involved in cell adhesion in both cell-extracellular matrix and cell-cell interactions, and particularly, $\beta 1$ integrin is involved in proliferation and differentiation of cells in the development of epithelial tissues. This work aimed to investigate the putative role of $\beta 1$ integrin expression on survival and metastasis in patients with breast invasive ductal carcinoma (IDC). In addition, we compared the expression of $\beta 1$ integrin in patients with ductal carcinoma in situ (DCIS).
\end{abstract}

Methods: Through tissue microarray (TMA) slides containing 225 samples of IDC and 67 samples of DCIS, $\beta 1$ integrin expression was related with several immunohistochemical markers and clinicopathologic features of prognostic significance.

Results: $\beta 1$ integrin was overexpressed in $32.8 \%$ of IDC. In IDC, $\beta 1$ integrin was related with HER-2 $(p=0.019)$ and $\operatorname{VEGF}(p=0.011)$ expression and it had a significant relationship with metastasis and death $(p=0.001$ and $p=0.05$, respectively). Kaplan-Meier survival analysis showed that the overexpression of this protein is very significant $(p=0.002)$ in specific survival (number of months between diagnosis and death caused by the disease). There were no correlation between IDC and DCIS ( $p=0.559)$ regarding $\beta 1$ integrin expression.

Conclusions: Considering that the expression of $\beta 1$ integrin in breast cancer remains controversial, specially its relation with survival of patients, our findings provide further evidence that $\beta 1$ integrin can be a marker of poor prognosis in breast cancer.

Virtual slides: The virtual slide(s) for this article can be found here: http://www.diagnosticpathology.diagnomx.eu/ vs/6652215267393871

Keywords: $\beta 1$ integrin, Tissue microarray, Immunohistochemistry, Prognosis

\section{Background}

Integrins are a family of transmembrane receptors. They are heterodimers composed by two subunits, $\alpha$ and $\beta$, which are non-covalently linked and depend of divalent cations [1]. A total of $18 \alpha$ and $8 \beta$ subunits have been identified. These subunits combine to form 24 distinct heterodimers, however splice variants have

\footnotetext{
*Correspondence: petrabarros@yahoo.com

'Department of Pathology, Laboratory of Immunopathology Keizo Asami, Federal University of Pernambuco, Avenida Professor Moraes Rêgo S/N, 50670-901 Recife, Pernambuco, Brazil

Full list of author information is available at the end of the article
}

been identified for some subunits and the number can reach at least 100 types [2,3]. These molecules can mediate intra and extracellular signals involved in the organization of cells, tissues and organs during development. Moreover they can directly or indirectly influence on many aspects of cell behavior, such adhesion, migration and proliferation. They also play a significant role in signal transduction events, such as gene expression and regulation of cell apoptosis $[4,5]$.

Invasive breast carcinoma is associated with a high mortality rate due to invasion to the lymph nodes, adjacent tissues and also due to metastasis. Invasive ductal

\section{Biomed Central}


carcinoma (IDC) is the most common histological type, accounting for approximately $40-75 \%$ of all cases. IDC has a relatively poor prognosis with $35-50 \% 10$-year survival rate [6,7]. Traditionally, as also verified in several other solid tumors, peritumoral lymphatic and blood invasion are the main factor related to the presence of lymph node metastasis and, in breast cancer, they are more closely related to tumor size and histological grade and it is known that integrins are closely related to these processes $[8,9]$.

$\beta 1$ integrin is the mainly expressed integrin in normal cells and in tumor-associated cells, in which they control various developmental processes including angiogenesis, tumor progression and metastasis [10]. These integrins typically mediate adhesion of epithelial cells to the basement membrane. They may also contribute to cell survival of tumor cells by interacting with others molecules. $\beta 1$ integrin usually activate cytokine receptors or growth factors receptors (FGRs) and as a result, the tumor growth and invasion probably depends on the crosstalk with certain integrins, FGRs and/or oncogenes in tumor cells and tumor-associated cells [11]. Based on these observations, $\beta 1$ integrin has become a target of interest for immunotherapy in several types of cancers, including breast cancer [12]. In recent years, several $\beta 1$ integrins antagonists have been studied $[13,14]$.

Over the last years, the study of ductal carcinoma in situ (DCIS) associated with invasive carcinoma has helped to understand the mechanisms involved in disease progression from DCIS to IDC [15]. Many studies have been reported conflicting results about the role of integrins in cancer cells and also in the patients' survival, and how these integrins may contribute to metastasis $[16,17]$. We aimed to evaluate the $\beta 1$ integrin expression in IDC and its relationship with several biomarkers and clinicopathologic features of prognostic significance. In addition, we compared the pattern of $\beta 1$ integrin expression in IDC and DCIS.

\section{Methods \\ Casuistic}

This study was approved by the local Research Ethics Committee. Formalin-fixed, paraffin-embedded samples of IDC and DCIS from 300 and 100 patients, respectively, diagnosed from 1994 to 2010, were randomly chosen from the archives of Department of PathologyRibeirão Preto Medical School, São Paulo University. The clinical data of these patients were retrieved from medical files, and included age, menopausal status, tumor size, metastasis to regional lymph nodes, recurrence, distant metastasis and death. Disease-specific survival, metastasis-free survival and disease-free survival were defined by Zanetti and colleagues [18].
For DCIS patients the following information was retrieved from clinical and pathological records: age, menstrual status, hormone receptors status (ER and PR), nuclear grade (low, intermediary and high), tumor size and if the tumor was multifocal or not.

\section{Tissue microarray (TMA)}

All hematoxylin and eosin stained slides were reviewed by an experienced breast pathologist (ARS). Three tissue microarrays (TMA) paraffin blocks were constructed from the IDC cases (100 cases per TMA) and five TMA paraffin blocks were constructed containing 24 DCIS cases per TMA. For the construction of the IDC and DCIS TMAs, core biopsies of $1-\mathrm{mm}$ diameter were punched from the selected regions of each donor paraffin blocks and arrayed into the TMA receptor block. One section of each was stained with hematoxylin and eosin to confirm the presence of the tumor by light microscopy. The three IDC's TMAs contained a total of 300 samples; however, 75 cases had to be excluded because of insufficient amount of tumor in the core. In that way, the study was performed in the 225 remaining cases that had high quality tissue spot that could be read for $\beta 1$ integrin and the others markers. DCIS's TMAs contained a total of 100 samples but only 67 had enough tumor tissue at the core, which were included in the analysis.

\section{Immunohistochemistry}

Sections $(3 \mu \mathrm{m})$ were obtained from the TMAs paraffin blocks and immunohistochemical reactions were performed with the Mach 4 Universal Polymer Detection kit (Biocare Medical, CA, USA) following protocols that were described elsewhere $[18,19]$. $\quad \beta 1$ integrin was detected using clone 4B7R (1:100) and VEGF with clone A-20 (1:100), both from Santa Cruz, Palo Alto, USA. The other antibodies are from Novocastra, Newcastle upon Tyne, UK: p53 (1:50, clone DO-7), ER (1:100, clone 6 F11), PR (1:100, clone 16), HER-2 (1:100, clone CB11) and Ki67 (1:100, clone MM1). Normal liver samples were used as positive control for $\beta 1$ integrin. IDC cases previously known to be positive for Ki67, ER, PR, p53, HER-2 were used as positive controls for each reaction. Negative controls were prepared omitting the primary antibody.

\section{Immunohistochemistry evaluation}

$\beta 1$ integrin cut-off was based according to Yao and colleagues [20] in which sample was scored based on the intensity of signal $(0,1+, 2+3+)$ and the percentage of positive cells $(0 \leq 10 \%, 1=10-25 \%, 2=25-50 \%, 3 \geq 50 \%)$. For statistical analysis we used the same method established by Petricevic and colleagues [21] where the results were presented as a positive (strong positive staining $3+$ 
and moderately positive staining $2+$ ) or a negative (weak positive $1+$ and negative staining 0 ) for tumor cells.

HER-2 was evaluated according to the ASCO/CAP HER2 guideline [22] and cases as 2+ were submitted to chromogenic in situ hybridization (CISH) [23]. Only HER-2 2+ cases in immunohistochemistry amplified on $\mathrm{CISH}$ were considered positive for statistical purposes. VEGF immunoscoring, according to Giatromanolaki and colleagues [24], was divided into two groups regarding the extent of positive staining: low/medium reactivity (0-69\% positive cells) and high reactivity (70-100\% positive cells).

For ER and PR we follow the recommendations of the ASCO/CAP ER/PR guidelines (2010) [25]. Ki67 was evaluated following Fountzilas and collegues [26] and cases were considered highly proliferative when more than $14 \%$ of neoplastic cells nuclei were positive. p53 were considered positive if more than $5 \%$ of the neoplastic cells showed nuclear staining [27].

\section{Chromogenic in situ hybridization (CISH)}

Sections $(3 \mu \mathrm{m})$ were cut from paraffin blocks of HER-2 cases with $2+$ immunohistochemistry positivity. ZytoDot 2C SPEC HER2/CEN 17 probe kit (Zytovision, Bremerhaven, Germany) was used for the detection of the human HER-2 gene and alpha-satellites of chromosome 17 (CEN 17). Procedures were according to manufacturer's instructions where two green (HER-2) and two red (CEN 17) signals were expected in a normal interphase nucleus. HER-2 was considered amplified when the HER-2/CEN 17 ratio was $\geq 2$ for 60 cells [28]. Only $2+$ biopsies by immunohistochemistry in which HER-2 was also amplified on CISH were considered positive.

\section{Statistical methods}

Data analysis was performed with SPSS v19.0 (SPSS Inc., Woking, UK) with $\mathrm{p}<0.05$ for significance. Relation between $\beta 1$ integrin, VEGF, HER-2 and the routine laboratory markers and clinicopathologic features were analyzed by Fisher exact test (two variables) or Chi-square tests (three or more variables), and all tests were two-tailed. Univariable survival analysis (disease-specific survival, disease-free survival and metastasis-free survival) were made with the log rank test and all results were displayed in Kaplan-Meier. A Cox Proportional Hazards Model was performed to observe the independent prognostic value of immunoexpression of $\beta 1$ integrin.

\section{Results}

Relationship between the expression of $\beta 1$ integrin with clinicopathological features and biological markers IDC cases with less than $50 \%$ of representative tumor area by hematoxilin eosin staining were excluded. Two hundred twenty five cases of IDC were then analyzed.
The average age of patients included in this study was 55 years old (range 25-85 years).

There was no significant relation between the expression of $\beta 1$ integrin with biomarkers such ER and PR. These results are shown in Table $1 . \beta 1$ integrin positive tumors did not correlate with tumor size, pathologic stage, age, menstrual status, lymph node status and tumor grade but presented a close relation with death and metastasis $(\mathrm{p}=0.001$ and $\mathrm{p}=0.05$, respectively) as well as with HER-2 ( $\mathrm{p}=0.019)$ and VEGF $(\mathrm{p}=0.011)$.

\section{Survival analysis}

Chi-square test for $\beta 1$ integrin and correlation for death and metastasis showed that 35 patients died and that 34 out of these had $\beta 1$ integrin superexpression and that 36 patients developed metastasis and that 26 out of them had $\beta 1$ integrin superexpression. The Kaplan-Meier test was used to estimate the survival time of patients that expressed or not $\beta 1$ integrin during the research time (maximum 164 months). Our results indicate that the expression of $\beta 1$ integrin has an impact in diseasespecific survival (number of months from diagnosis to the time of death due to breast cancer) with $\mathrm{p}=0.002$ (Figure 1). For metastasis-free survival (Figure 2) and disease-free survival (Figure 3) no significant relation was observed ( $\mathrm{p}=0.061$ and $\mathrm{p}=0,252$, respectively).

A Cox Proportional Hazards Model was performed to observe the independent prognostic value of $\beta 1$ integrin expression with several prognostic factors such menopausal status, clinical stage, Bloom-Richardson, recurrence, but no correlation was found; data not shown.

\section{IDC $\times$ DCIS}

The expression of $\beta 1$ integrin was also evaluated in 67 patients with DCIS. The average age of patients included in this study was 51 years old (range 23-84 years). Forty-two cases were presented as multifocal and the architectural pattern was mostly solid, comedo and cribriforme, and in our casuistic, 42 cases was associated with invasive carcinoma. Representative samples of IDC and DCIS are shown in Figure 4. There was no significant relation between the expression of the $\beta 1$ integrin in DCIS with clinical and pathological factors of prognostic significance. Twenty-two patients were positive for $\beta 1$ integrin where 10 were pre-menopausal and 12 were post-menopausal. Nineteen presented high nuclear grade and only three patients had low nuclear grade.

The relation between the expression of biomarkers, such as ER and PR, and $\beta 1$ integrin in IDC and DCIS were not significant (Table 2).

\section{Discussion}

According to Kononen and colleagues [29] tissue microarrays (TMAs) were developed to allow high throughput 
analysis of protein expression in tumors tissues and many authors agree that they can be used to validate biomarkers [30-32]. Here, $\beta 1$ integrin expression and its relationship with survival of patients with IDC were analyzed in a tissue microarray.

During the last years a number of reports have linked integrins to tumorigenicity ranging from local tumor growth to metastasis [33] and it is well documented that integrins contribute to migration and invasion of cancer cells [34]. $\beta 1$ integrin is the most widely expressed integrin in cells and has been suggested to play a role in predicting the clinical course and prognosis of several types of cancers [20]. However, Brakebusch and colleagues [35] argue that it is not surprising that some studies link tumorigenicity to $\beta 1$ integrin in the form of down- or up-regulated expression. For example, according to Guo and colleagues [36] $\beta 1$ integrin is the most abundantly expressed integrin in Non-small-cell lung carcinoma and

Table 1 Relationship between $\beta 1$ integrin expression with clinicopathologic features and classical immunohistochemical markers in breast cancer, including VEGF

\begin{tabular}{|c|c|c|c|c|c|c|}
\hline \multirow{2}{*}{$\begin{array}{l}\text { Clinicopathologic } \\
\text { Features and } \\
\text { Immunohistochemical } \\
\text { Markers }\end{array}$} & & \multicolumn{2}{|c|}{$\beta 1$ Integrin $^{-}$} & \multicolumn{2}{|c|}{$\beta 1$ Integrin $^{+}$} & \multirow[t]{2}{*}{$P$-value } \\
\hline & & $n(151)$ & (\%) & $\mathrm{n}(74)$ & (\%) & \\
\hline \multirow[t]{2}{*}{ Age (years) } & $<50$ & 65 & 43.0 & 27 & 36.5 & $0.213^{a}$ \\
\hline & $>50$ & 86 & 67.0 & 47 & 63.5 & \\
\hline \multirow[t]{2}{*}{ Menstrual Status } & Pre-menopausal & 54 & 35.8 & 24 & 32.4 & $0.367^{\mathrm{a}}$ \\
\hline & Post-menopausal & 97 & 64.2 & 50 & 67.6 & \\
\hline \multirow[t]{3}{*}{ Size (mm) } & $<20$ & 49 & 32.5 & 19 & 25.7 & $0.442^{b}$ \\
\hline & $20-50$ & 55 & 36.4 & 33 & 44.6 & \\
\hline & $>50$ & 47 & 31.1 & 22 & 29.7 & \\
\hline \multirow[t]{3}{*}{ Tumoral Grade } & 1 & 57 & 37.7 & 25 & 33.8 & $0.845^{b}$ \\
\hline & $\|$ & 71 & 47.0 & 37 & 50.0 & \\
\hline & III & 23 & 15.2 & 12 & 16.2 & \\
\hline \multirow[t]{2}{*}{ Lymph node Status } & Negative & 75 & 49.7 & 33 & 44.6 & $0.283^{a}$ \\
\hline & Positive & 76 & 50.3 & 41 & 55.4 & \\
\hline \multirow[t]{4}{*}{ Clinical Stage } & । & 22 & 14.6 & 10 & 13.5 & $0.677^{b}$ \\
\hline & $\|$ & 72 & 47.7 & 30 & 40.5 & \\
\hline & III & 49 & 32.5 & 30 & 40.5 & \\
\hline & IV & 8 & 5.3 & 4 & 5.4 & \\
\hline \multirow[t]{2}{*}{ Death } & No & 116 & 76.8 & 40 & 54.1 & $0.001^{a}$ \\
\hline & Yes & 35 & 23.2 & 34 & 45.9 & \\
\hline \multirow[t]{2}{*}{ Metastasis } & No & 115 & 76.2 & 48 & 64.9 & $0.05^{a}$ \\
\hline & Yes & 36 & 23.8 & 26 & 35.1 & \\
\hline \multirow[t]{2}{*}{ ER } & Negative & 48 & 31.8 & 21 & 28.4 & $0.359^{a}$ \\
\hline & Positive & 103 & 68.2 & 53 & 71.6 & \\
\hline \multirow[t]{2}{*}{ PR } & Negative & 64 & 42.4 & 33 & 44.6 & $0.431^{a}$ \\
\hline & Positive & 87 & 57.6 & 41 & 55.4 & \\
\hline \multirow[t]{2}{*}{ p53 } & Negative & 114 & 75.5 & 51 & 68.9 & $0.187^{a}$ \\
\hline & Positive & 37 & 24.5 & 23 & 31.1 & \\
\hline \multirow[t]{2}{*}{ Ki-67 } & Negative & 107 & 70.9 & 54 & 73.0 & $0.435^{\mathrm{a}}$ \\
\hline & Positive & 44 & 29.1 & 20 & 27.0 & \\
\hline \multirow[t]{2}{*}{ HER2 } & Negative & 126 & 83.4 & 52 & 70.3 & $0.019^{a}$ \\
\hline & Positive & 25 & 16.6 & 22 & 29.7 & \\
\hline \multirow[t]{2}{*}{ VEGF } & Negative & 114 & 75.5 & 66 & 89.2 & $0.011^{a}$ \\
\hline & Positive & 37 & 24.5 & 8 & 10.8 & \\
\hline
\end{tabular}




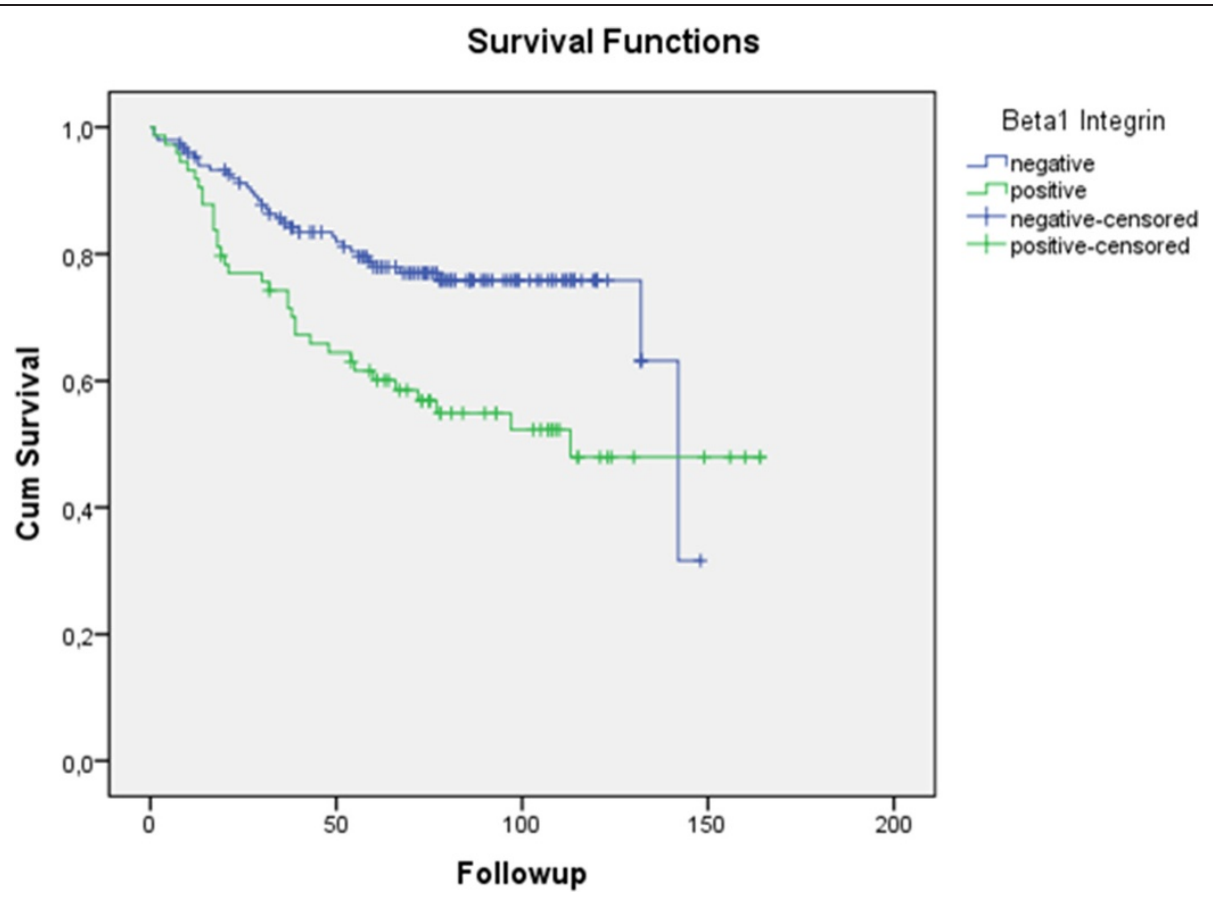

Figure 1 Univariate analysis: the prognostic impact of $\beta 1$ integrin status on disease-specific survival of breast cancer patients $(\mathbf{p}=\mathbf{0 . 0 0 2})$. (Using Kaplan-Meier table followed by log-rank test).

other authors [37] founded that its expression has been associated with lymph node metastasis in the same type of cancer. Although Kren and colleagues [38] noted that the low expression of $\beta 1$ integrin promoted tumor cells dissemination in a mouse model of pancreatic $\beta$ cell carcinogenesis.

In regard to breast cancer, some studies have reported that decreased $\beta 1$ integrin expression was associated

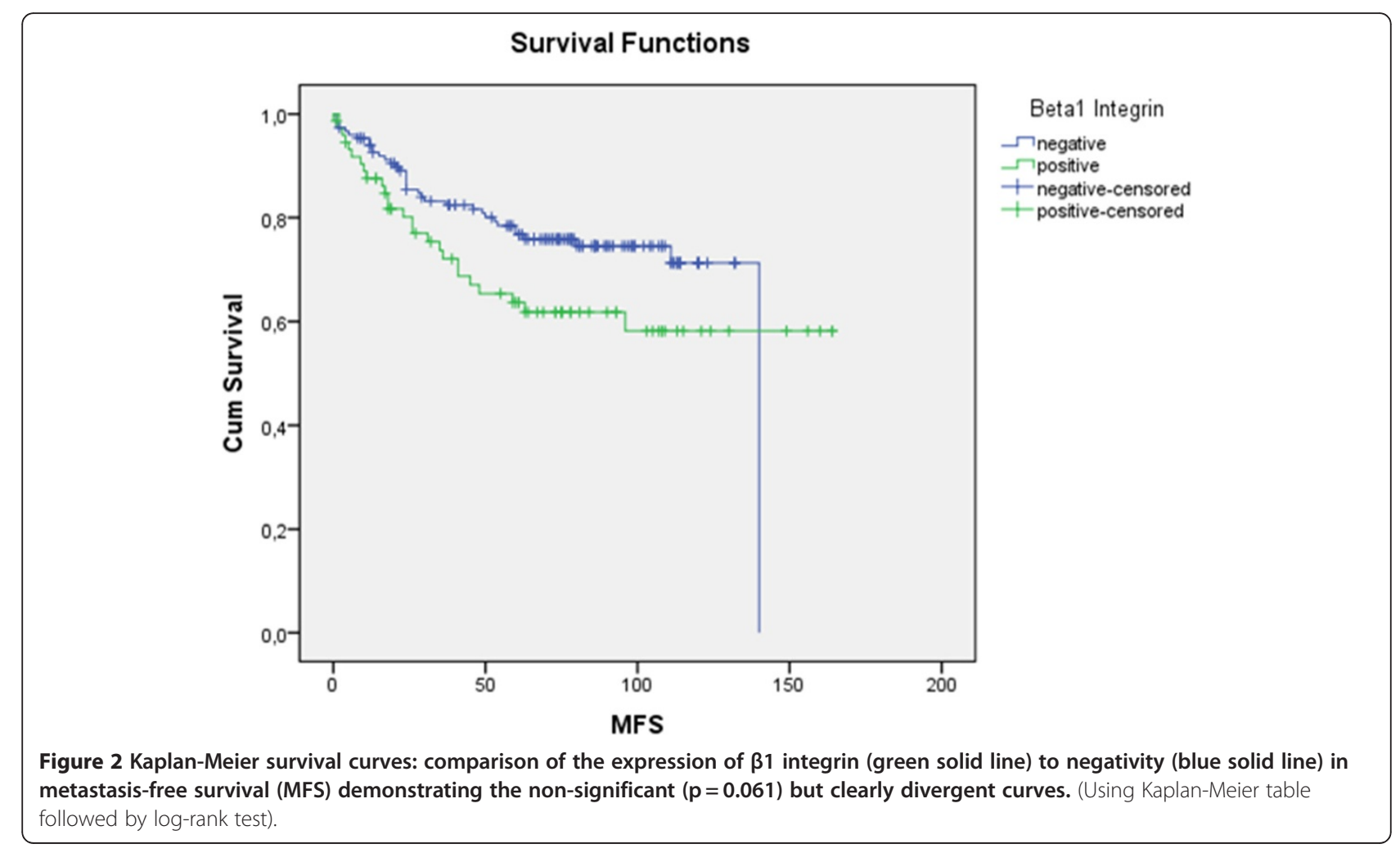



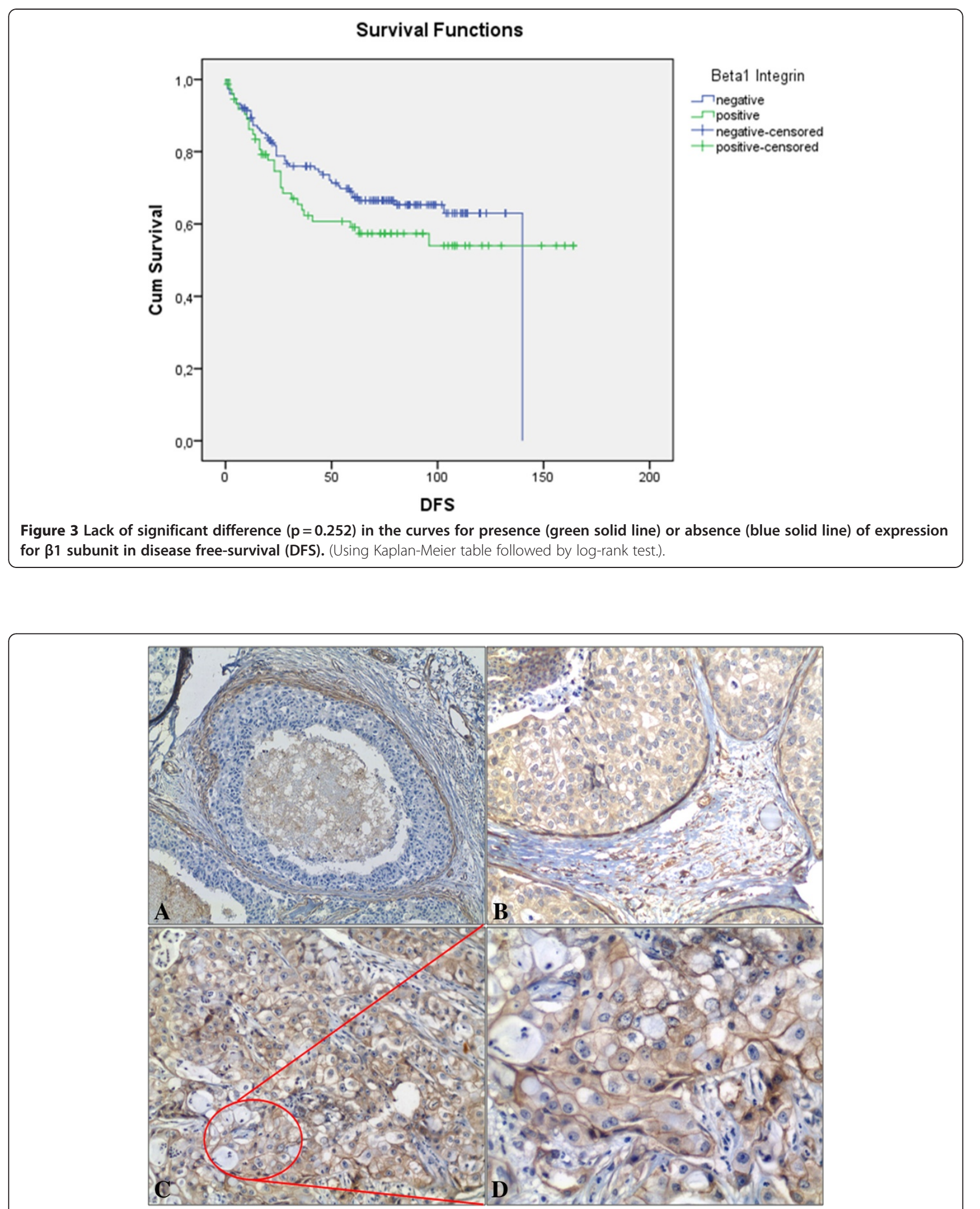

Figure 4 Immunohistochemistry for $\beta 1$ integrin in Invasive and In situ Breast Carcinoma. DCIS: (A) negative (100x) and (B) positive (200X); IDC: (C) positive (200x) and (D) detail with 400x of the circled area. $\beta 1$ integrin can be found both in cytoplasm and plasma membrane. (SP method, high power microscopic view). 


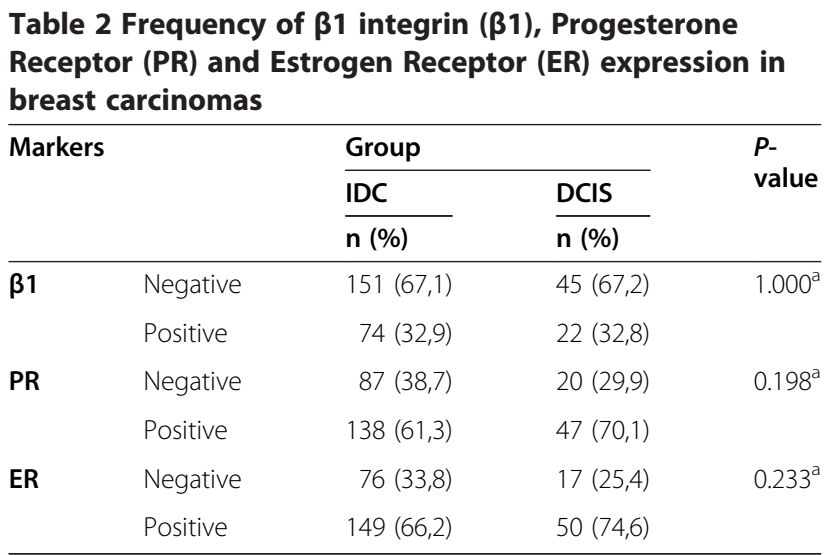

with characteristics of more aggressive disease [39,40], while others observed that the high expression of $\beta 1$ integrin is associated with decrease survival [20]. Berry and colleagues [41] and Petricevic and co-workers [21] verified no significant correlation with $\beta 1$ integrin expression and survival of patients with breast carcinoma. Then, it is possible to realize that there are controversies in the studies concerning the expression of this protein as well as its relation with survival rate in patients with breast cancer.

We choose the same score used by Yao and colleagues [20] based on the level of signal and percentage of tumor cells expressing the signal. Here, we provide evidences that $\beta 1$ integrin high expression $(2+$ and $3+)$ can be predictive of response and has impact on specific-free survival in patients with breast cancer. Ours findings did not relate $\beta 1$ integrin with metastasis free survival. Some authors suggested that $\beta 1$ integrin is important but not essential for metastasis [35]. All these findings are in accordance with previous reports in different types of cancer [42-44], including previous studies that showed that $\beta 1$ integrin inhibition induces apoptosis in breast cancer cells [45].

The basement membranes are reservoirs for growth factors [46] and it is well known that specific integrins can activate specific FGRs [11]. For example, Hayashida and colleagues [47] founded that $\beta 1$ integrin are dependently linked with TGF- $\beta 1$, and that knocking $\beta 1$ integrin down enhances the cell collagen production trough TGF- $\beta 1$. Nowadays, it is well known that the interaction between FGRs and integrins can regulate cell survival and proliferation and supporting tumor growth $[48,49]$.

Some studies linked $\beta 1$ integrin with members of the FGR family including VEGF [50]. This can promote angiogenesis through up-regulation and/or activation of integrins [51]. Other study demonstrated that VEGF activity is dependent on $\beta 1$ integrin function. In this study the authors founded that the knockout of $\beta 1$ integrin in embryonic stem cells, neither the proliferation of the endothelial cells nor sprouting of blood vessels occurred, suggesting that VEGF had no effect in $\beta 1$-null embryoid bodies [52]. More interestingly Lee and colleagues [51] with in vitro studies, with human brain microvascular endothelial cells, showed that blocking $\beta 1$ integrin, all processes of angiogenesis was inhibited (adhesion, migration, and capillary morphogenesis) and they also suggested that the $\alpha 6 \beta 1$ integrin is closely related to the metastasis of breast cancer cells to the brain.

Studies have demonstrated that some oncogenes require specific integrins for tumorigenicity. Integrins are not oncogenic molecules, but some of them can cooperate with oncogene to initiate growth, invasion and progression of the cancer [11]. In a transgenic mouse model of human breast cancer some authors founded that $\beta 1$ integrin mediates the initiation of mammary tumorigenesis that is driven by the polyoma middle $\mathrm{T}$ oncoprotein [53].

Recent data suggest a relationship between HER-2 and $\beta 1$ integrin. Shimizu and colleagues [54], in a study with breast cancer cell line, suggested that the $\alpha 6 \beta 1$ integrin inhibits HER-2 signals by proteolytic cleavage of the cytoplasmic domain of HER-2 and this could also contribute to the regulation of tumor growth. Other authors [55] demonstrated that even under adverse conditions such as hypoxia and chemotherapeutic treatments there is a strong regulation between HER-2 signaling stimulating the expression of the integrin $\alpha 5$ and $\beta 1$ which promotes tumor cell survival.

In the present study, we found a relationship between low expression of $\beta 1$ integrin and negativity for HER-2 demonstrating some evidence that this subgroup of patients might have a less aggressive phenotype. Besides, we showed that patients who had high $\beta 1$ integrin expression showed the poor prognostic.

Angiogenesis is induced by VEGF through its interaction with receptors expressed primarily on the vascular endothelial cell membrane [18] and is well known that tumors depend largely on effective angiogenesis [35]. The amplification of the proto-oncogene HER-2 is observed in approximately $15-30 \%$ of all breast cancer samples and has been correlated with a shorter survival $[23,56]$. An important aspect of the involvement of $\beta 1$ integrin in angiogenesis and tumorigenicity is the potential implication for tumor treatment [57]. This study shows that $\beta 1$ integrin expression on tumor cells actually promote tumor progression and acts as a tumor enhancer. In addition, our results indicate that both expression of the $\beta 1$ integrin and its association with HER-2 and VEGF may be useful in targeted therapies for patients with breast cancer.

One of the main focuses concerning breast cancer has been the identification of the molecular alterations associated with the different stages of the progression disease. According to Bombonati and Sgroi [7] the current model of human breast cancer progression proposes a 
linear multi-step process which initiates as flat epithelial atypia, progresses to atypical ductal hyperplasia, evolves into DCIS and culminates in the potentially lethal stage of IDC. In our study we do not found association with the expression of $\beta 1$ integrin in IDC and DCIS. $67,1 \%$ of the IDC cases were negative for $\beta 1$ integrin and $67,2 \%$ were negative in DCIS cases, with no significant relation probably due to the limited number of cases.

\section{Conclusions}

Subgroups of patients with negativity for $\beta 1$ integrin and HER-2 might have a less aggressive phenotype. Taken together with the differential expression of VEGF these findings may be useful in targeted therapies for patients with breast cancer. Although there was no association between $\beta 1$ integrin expression in IDC and DCIS the relationship in these types of cancer needs to be better understood, and further studies are needed to clarify the molecular basis involved in this process.

\section{Competing interests}

The authors declare that they have no competing interests.

\section{Authors' contributions}

PBS: participated in conception and design, acquisition of data, analysis and interpretation of data, carry out all of the experiments; JSZ: participated in analysis and interpretation of data, carry out part of the experiments; ARS: participated in study design and coordination, and revising it critically for important intellectual content. EICB: help in material support for obtained and funding, and supervised study. All authors read and approved the final manuscript.

\section{Acknowledgments}

We thank CNPq (Conselho Nacional de Desenvolvimento Científico e Tecnológico, Brazil) and FAPESP (Fundação de Amparo a Pesquisa do Estado de São Paulo, Brazil) for financial support, CAPES (Coordenação de Aperfeiçoamento de Pessoal de Nível Superior, Brazil) and FACEPE (Fundação de Amparo à Ciência e Tecnologia do Estado de Pernambuco, Brazil) for schollarships and financial support; and Deisy Mara da Silva for technical assistance.

This research is in accordance with Declaration of Helsinki, and was aprooved by the local ethics comitee.

\section{Author details}

${ }^{1}$ Department of Pathology, Laboratory of Immunopathology Keizo Asami, Federal University of Pernambuco, Avenida Professor Moraes Rêgo S/N, 50670-901 Recife, Pernambuco, Brazil. ²Department of Pathology, Ribeirão Preto Medical School, University of São Paulo, Ribeirão Preto, São Paulo 14049-900, Brazil. ${ }^{3}$ Department of Biochemistry, Federal University of Pernambuco, Recife, Pernambuco 50670-901, Brazil.

Received: 28 May 2012 Accepted: 10 August 2012

Published: 16 August 2012

\section{References}

1. Hynes RO: Integrins: bidirectional, allosteric signaling machines. Cell 2002, 110(6):673-687.

2. Melker AA, Sonnenberg A: Integrins: alternative splicing as a mechanism to regulate ligand binding and integrin signaling events. Bioessays 1999 , 21(6):499-509.

3. Gilcrease MZ: Integrin signaling in epithelial cells. Cancer Lett 2007, 247(1):1-25.

4. Seftor REB: Role of the beta3 integrin subunit in human primary melanoma progression: multifunctional activities associated with alpha (v)beta3 integrin expression. Am J Pathol 1998,

153(5):1347-1351.
5. Ellis SJ, Tanentzapf G: Integrin-mediated adhesion and stem-cell-niche interactions. Cell Tissue Res 2010, 339(1):121-130.

6. Tavassoli FA, Devilee P: World health organization classification of tumours: pathology and genetics of tumours of the breast and female genital organs. Lyon: IARCPress; 2003.

7. Bombonati A, Sgroi DC: The molecular pathology of breast cancer progression. J Pathol 2011, 223(2):307-317.

8. Mizejewski GJ: Role of integrins in cancer: survey of expression patterns. Proc Soc Exp Biol Med 1999, 222(2):124-138.

9. Weigelt B, Peterse JL, Van't Veer $\amalg$ : Breast cancer metastasis: markers and models. Nat Rev Cancer 2005, 5(8):591-602.

10. Li N, Zhang Y, Naylor MJ, Schatzmann F, Maurer F, Wintermantel T, Schuetz G, Mueller U, Streuli CH, Hynes NE: Beta integrins regulates mammary proliferation and maintain the integrity of mammary alveoli. EMBO J 2005, 24(11):1942-1953.

11. Desgrosellier JS, Cheresh DA: Integrins in cancer: biological implications and therapeutic opportunities. Nat Rev Cancer 2010, 10(1):9-22.

12. Park CC, Zhang HJ, Yao ES, Park CJ, Bissell MJ: Beta1 integrin inhibition dramatically enhances radiotherapy efficacy in human breast cancer xenografts. Cancer Res 2008, 68(11):4398-4405.

13. Bhaskar $V$, Zhang D, Fox M, Seto P, Wong MH, Wales PE, Powers D, Chao DT, Dubridge RB, Ramakrishnan V: A function blocking anti-mouse integrin alpha5beta1 antibody inhibits angiogenesis and impedes tumor growth in vivo. J Transl Med 2007, 5(61):1-11.

14. Ricart AD, Tolcher AW, Liu G, Holen K, Schwartz G, Albertini M, Weiss G, Yazji S, Ng C, Wilding G: Volociximab, a chimeric monoclonal antibody that specifically binds alpha5beta1 integrin: a phase I, pharmacokinetic, and biological correlative study. Clin Cancer Res 2008 14(23):7924-7929.

15. Van Diest PJ: Ductal carcinoma in situ in breast carcinogenesis. $J$ Pathol 1999, 187(4):383-384.

16. Ramirez NE, Zhang Z, Madamanchi A, Boyd KL, O'Rear LD, Nashabi A, Li Z, Dupont WD, Zijlstra A, Zutter MM: The $a_{2} \beta_{1}$ integrin is a metastasis suppressor in mouse models and human cancer. J Clin Invest 2011, 121(1):226-237.

17. Koistinen $\mathrm{P}$, Ahonen $\mathrm{M}$, Kähäri VM, Heino J: alphaV integrin promotes in vitro and in vivo survival of cells in metastatic melanoma. Int J Cancer 2004, 112(1):61-70.

18. Zanetti JS, Soave DF, Oliveira-Costa JP, da Silveira GG, Ramalho LN, Garcia SB, Zucoloto S, Ribeiro-Silva A: The role of tumor hypoxia in MUC1-positive breast carcinomas. Virchows Arch 2011, 459(4):367-375.

19. Ribeiro-Silva A, Moutinho MA H, Moura B, Vale FR, Zucoloto S: Expression of checkpoint kinase 2 in breast carcinomas: correlation with key regulators of tumor cell proliferation, angiogenesis, and survival. Histol Histopathol 2006, 21(4):373-382.

20. Yao ES, Zhang H, Chen YY, Lee B, Chew K, Moore D, Park C: Increased beta1 integrin is associated with decreased survival in invasive breast cancer. Cancer Res 2007, 67(2):659-664.

21. Petricevic B, Vrbanec D, Jakic-Razumovic J, Brcic I, Rabic D, Badovinac T, Ozimec E, Bali V: Expression of Toll-like receptor 4 and beta 1 integrin in breast cancer. Med Oncol 2012, 29:486-494.

22. Wolff AC, Hammond ME, Schwartz JN, Hagerty KL, Allred DC, Cote RJ, Dowsett M, Fitzgibbons PL, Hanna WM, Langer A, McShane LM, Paik S, Pegram MD, Perez EA, Press MF, Rhodes A, Sturgeon C, Taube SE, Tubbs R, Vance GH, van de Vijver M, Wheeler TM, Hayes DF: American Society of Clinical Oncology/College of American Pathologists: American society of clinical oncology/college of american pathologists guideline recommendations for human epidermal growth factor receptor 2 testing in breast cancer. Arch Pathol Lab Med 2007, 131:18-43.

23. Oliveira-Costa JP, Zanetti J, Oliveira LR, Soares FA, Ramalho LZ, Silva Ramalho F, Garcia SB, Ribeiro-Silva A: Significance of topoisomerase $I I I$ expression in breast ductal carcinomas: strong associations with disease-specific survival and metastasis. Hum Pathol 2010, 41(11):1624-1630.

24. Giatromanolaki A, Koukourakis MI, Sivridis E, Pastorek J, Wykoff CC, Gatter KC, Harris AL: Expression of hypoxia-inducible carbonic anhydrase- 9 relates to angiogenic pathways and independently to poor outcome in non-small cell lung cancer. Cancer Res 2001, 61(21):7992-7998. 
25. Hammond ME, Hayes DF, Dowsett M, et al: American society of clinical oncology/college of American pathologists guideline recommendations for immunohistochemical testing of estrogen and progesterone receptors in breast cancer. J Clin Oncol 2010, 28(16):2784-2795.

26. Fountzilas G, Dafni U, Bobos M, Batistatou A, Kotoula V, Trihia H, Malamou-Mitsi V, Miliaras S, Chrisafi S, Papadopoulos S, Sotiropoulou M, Filippidis T, Gogas H, Koletsa T, Bafaloukos D, Televantou D, Kalogeras KT, Pectasides D, Skarlos DV, Koutras A, Dimopoulos MA: Differential response of immunohistochemically defined breast cancer subtypes to anthracycline-based adjuvant chemotherapy with or without paclitaxel. PLoS One 2012, 7(6):e37946.

27. Ercan C, van Diest PJ, van der Ende B, Hinrichs J, Bult P, Buerger $H$, van der Wall E, Derksen PW: p53 mutations in classic and pleomorphic invasive lobular carcinoma of the breast. Cell Oncol 2012, 35:111-118.

28. O'connell JT, Zhi-Ming S, Ehud D, Basbaum CB, Barsky SH: Altered mucin expression is a field change that accompanies mucinous (colloid) breast carcinoma histogenesis. Hum Pathol 1998, 29(12):1517-1523.

29. Kononen J, Bubendorf L, Kallioniemi A, Bärlund M, Schraml P, Leighton S Torhorst J, Mihatsch MJ, Sauter G, Kallioniemi OP: Tissue microarrays for high-throughput molecular profiling of tumor specimens. Nat Med 1998, 4(7):844-847.

30. Zhang DH, Salto-Tellez M, Putti TC, Do E, Koay ES-C: Reliability of tissue microarrays in detecting protein expression and gene amplification in breast cancer. Mod Pathol 2003, 16(1):79-85.

31. Hassan S, Ferrario C, Mamo A, Basik M: Tissue microarrays: emerging standard for biomarker validation. Curr Opin Biotechnol 2008, 19(1):19-25.

32. Lawson $\mathrm{MH}$, Cummings $\mathrm{NM}$, Rassl DM, Vowler SL, Wickens $\mathrm{M}$, Howat WJ, Brenton JD, Murphy G, Rintoul RC: BCl-2 and $\beta 1$-integrin predict survival in a tissue microarray of small cell lung cancer. $\mathrm{Br} J$ Cancer 2010, 103(11):1710-1715.

33. Varner JA, Cheresh DA: Integrins and cancer. Curr Opin Cell Biol 1996 8(5):724-730.

34. Guo W, Pylayeva Y, Pepe A, Yoshioka T, Muller WJ, Inghirami G, Giancotti FG: Beta 4 integrin amplifies ErbB2 signaling to promote mammary tumorigenesis. Cell 2006, 126(3):489-502.

35. Brakebusch $C$, Hirsch E, Potocnik A, Fässler R: Genetic analysis of $\beta 1$ integrin function: confirmed, new and revised roles for a crucial family of cell adhesion molecules. J Cell Sci 1997, 110(23):2895-2904.

36. Guo L, Zhang F, Cai Y, Liu T: Expression profiling of integrins in lung cancer cells. Pathol Res Pract 2009, 205(12):847-853.

37. Dingemans AM, van den Boogaart $V$, Vosse BA, van Suylen RJ, Griffioen AW, Thijssen $V L$ : Integrin expression profiling identifies integrin alpha5 and beta1 as prognostic factors in early stage non-small cell lung cancer. $\mathrm{Mol}$ Cancer 2010, 9(152):1-9.

38. Kren A, Baeriswyl V, Lehembre F, Wunderlin C, Strittmatter K, Antoniadis H, Fässler R, Cavallaro U, Christofori G: Increased tumor cell dissemination and cellular senescence in the absence of beta1-integrin function. $E M B O$ J 2007, 26(12):2832-2842

39. Gonzalez MA, Pinder SE, Wencyk PM, Bell JA, Elston CW, Nicholson RI Robertson JF, Blamey RW, Ellis IO: An immunohistochemical examination of the expression of E-cadherin, alpha- and beta/gamma-catenins, and alpha2- and beta1- integrins in invasive breast cancer. J Pathol 1999, 187(5):523-529.

40. Lanzafame S, Emmanuele C, Torrisi A: Correlation of alpha 2 beta 1 integrin expression with histological type and hormonal receptor status in breast carcinomas. Pathol Res Pract 1996, 192(10):1031-1038.

41. Berry MG, Gui GP, Wells CA, Carpenter R: Integrin expression and survival in human breast cancer. Eur J Surg Oncol 2004, 30(5):484-489.

42. Adachi M, Taki T, Higashiyama M, Kohno N, Inufusa H, Miyake M: Significance of integrin alpha5 gene expression as a prognostic factor in node-negative non-small cell lung cancer. Clin Cancer Res 2000, 6(1):96-101.

43. Ahmed N, Riley C, Rice G, Quinn M: Role of integrin receptors for fibronectin, collagen and laminin in the regulation of ovarian carcinoma functions in response to a matrix microenvironment. Clin Exp Metastasis 2005, 22(5):391-402.

44. Bottger TC, Maschek H, Lobo M, Gottwohl RG, Brenner W, Junginger T: Prognostic value of immunohistochemical expression of beta-1 integrin in pancreatic carcinoma. Oncology 1999, 56(4):308-313.

45. Park CC, Zhang H, Pallavicini M, Gray JW, Baehner F, Park CJ, Bissell MJ: Beta1 integrin inhibitory antibody induces apoptosis of breast cancer cells, inhibits growth and distinguishes malignant form normal phenotype in three dimensional cultures and in vivo. Cancer Res 2006, 66(3):1526-1535.

46. Adams JC, Watt FM: Regulation of development and differentiation by the extracellular matrix. Development 1993, 117(4):1183-1198.

47. Hayashida T, Jones JC, Lee CK, Schnaper HW: Loss of beta1-integrin enhances TGF-beta1-induced collagen expression in epithelial cells via increased alphavbeta3-integrin and Rac1 activity. J Biol Chem 2010, 285(40):30741-39751.

48. Walker $J$, Fournier AK, Assoian RK: Regulation of growth factor signaling and cell cycle progression by cell adhesion and adhesiondependent changes in cellular tension. Cytokine Growth Factor Rev 2005, 16(4-5):395-405

49. Klein EA, Yung Y, Castagnino P, Kothapalli D, Assoian RK: Cell adhesion, cellular tension, and cell cycle control. Methods Enzymol 2007, 426:155-175.

50. Morello V, Cabodi S, Sigismund S, Camacho-Leal MP, Repetto D, Volante M, Papotti M, Turco E, Defilippi P: $\beta 1$ integrin controls EGFR signaling and tumorigenic properties of lung cancer cells. Oncogene 2011, 30(39):4087-4096.

51. Lee TH, Seng S, Li H, Kennel SJ, Avraham HK, Avraham S: Integrin regulation by vascular endothelial growth factor in human brain microvascular endothelial cells: role of alpha6beta1 integrin in angiogenesis. J Biol Chem 2006, 281(52):40450-40460.

52. Bloch W, Forsberg E, Lentini S, Brakebusch C, Martin K, Krell HW, Weidle UH, Addicks K, Fässler R: Beta 1 integrin is essential for teratoma growth and angiogenesis. J Cell Biol 1997, 139(1):265-278.

53. White DE, Kurpios NA, Zuo D, Hassell JA, Blaess S, Mueller U, Muller WJ: Targeted disruption of beta1-integrin in a transgenic mouse model of human breast cancer reveals an essential role in mammary tumor induction. Cancer Cell 2004, 6(2):159-170.

54. Shimizu H, Seiki T, Asada M, Yoshimatsu K, Koyama N: Alpha6beta1 integrin induces proteasome-mediated cleavage of erbB2 in breast cancer cells. Oncogene 2003, 22(6):831-839.

55. Spangenberg C, Lausch EU, Trost TM, Prawitt D, May A, Keppler R, Fees SA, Reutzel D, Bell C, Schmitt S, Schiffer IB, Weber A, Brenner W, Hermes M, Sahin U, Türeci O, Koelbl H, Hengstler JG, Zabel BU: ERBB2-mediated transcriptional up-regulation of the alpha5beta1 integrin fibronectin receptor promotes tumor cell survival under adverse conditions. Cancer Res 2006, 66(7):3715-3725.

56. Borg A, Tandon AK, Sigurdsson H, Clark GM, Fernö M, Fuqua SA, Killander D, McGuire WL: HER-2/neu amplification predicts poor survival in node-positive breast cancer. Cancer Res 1990, 50(14):4332-4337.

57. Hanahan D, Folkman J: Patterns and emerging mechanisms of the angiogenic switch during tumorigenesis. Cell 1996, 86(3):353-364.

doi:10.1186/1746-1596-7-104

Cite this article as: dos Santos et al:: Beta 1 integrin predicts survival in breast cancer: a clinicopathological and immunohistochemical study. Diagnostic Pathology 2012 7:104.

\section{Submit your next manuscript to BioMed Central and take full advantage of:}

- Convenient online submission

- Thorough peer review

- No space constraints or color figure charges

- Immediate publication on acceptance

- Inclusion in PubMed, CAS, Scopus and Google Scholar

- Research which is freely available for redistribution 